\title{
МОНГОЛ УЛСЫН ТӨСВИЙН ХӨРӨНГӨ ОРУУЛАЛТЫН ҮР АШГИЙН СУДАЛГАА
}

\begin{abstract}
In brief, the legislations and purposes of the budget investment policy of Mongolia have been taken into account in this survey. The budget investment growth, total budget expenditure and the changes of the density to GDP since 1990 on dynamic growth method have been studied by using the official sources like National Statistical Office of Mongolia and the Ministry of Finance. Moreover, I summarized the budget investment efficiency by using the Incremental Capital-Output Ratio method (hereinafter referred to as ICOR) and data of the National Statistical Office of Mongolia from 2002 to 2012.

GDP and investment indicators are computed at 2005 constant prices. Investment at current prices was multiplied with the deflator of the year 2005 to convert to at 2005 constant prices.

Although, as the result of the analysis, the amount of budget investment cost and its density to GDP and state budget expenditure are increasing, investment budget is still not efficient enough. Accordingly, it is recommended to increase the budget investment benefit and to sophisticate its composition.
\end{abstract}

\section{Товч агуулга, судалгааны аргачлал}

Энэхүү судалгааны ажлын хүрээнд Монгол улсын төсвийн хөрөнгө оруулалтын бодлогын зорилго, хууль эрхзүйн үндсийг товч авч үзсэн. Мөн 1990 оноос хойшхи хугацааны төсвийн хөрөнгө оруулалтын хэмжээний өсөлт, нийт төсвийн зарлага болон ДНБ-д эзлэх хувийн жингийн өөрчлөлтийг МУҮСХ, Сангийн яам зэрэг албан эх үүсвэрээс авсан тоон мэдээлэл дээр үндэслэн динамик өсөлтийн аргаар судаллаа. Төсвийн хөрөнгө оруулалтын үр ашгийн тооцоог 2002-2012 оны МУҮСХноос гаргасан тоон мэдээллийг ашиглан, Нэмэгдүүлсэн хөрөнгө - гарцын харьцааны apraap (Incremental Capital-Output Ratio, цаашид ICOR гэx) шинжилж дүгнэлт гаргасан. ДНБ болон хөрөнгө оруулалтын үзүүлэлтүүдийг 2005 оны зэрэгцүүлэх үнээр авсан бөгөөд хөрөнгө оруулалтын оны үнийг 2005 оны зэрэгцүүлэх үнэд шилжүүлэхдээ тухайн оны дефлятороор үржүүллээ. Шинжилгээний үр дүнгээс үзэхэд төсвийн хөрөнгө оруулалтын зардлын хэмжээ, түүний ДНБ болон төсвийн нийт зарлагад эзлэх хувийн жин өссөөр байгаа хэдий ч төсвийн хөрөнгө оруулалтын үр ашиг хангалтгүй байна. Иймээс төсвийн хөрөнгө оруулалтын үр ашгийг нэмэгдүүлж, түүний бүтцийг сайжруулах чиглэлээр тодорхой ажпуудыг хийх хэрэгтэй юм.

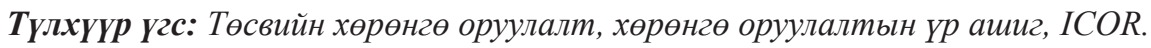

\section{Оршил}

Монгол Улсын хөгжпийн тулгуур засаг, нийгмийн хөгжлийг дэлхийн зорилтуудын нэг нь улс орны эдийн чиг хандлагатай нийцүүлэн хурдасгах, 
ядуурлыг бууруулж, хүн амын амьдралын төвшинг эрс дээшлүүлэх явдал бегөед үүнд хүрэх гол арга зам нь хөрөнгө оруулалтын бодлогыг боловсронгуй болгож, улсын болон төсвийн хөрөнгө оруулалтыг нэмэгдүүлэн, үр өгөөжийг нь нэмэгдүүлэх асуудал юм. Иймээс ч хөрөнгө оруулалтын

\section{Судлагдсан байдал}

Монгол улсын нийт болон төсвийн хөрөнгө оруулалтын үр ашгийг нэлээд хэдэн судлаачид тооцох оролдлого хийсэн байдаг. Тухайлбал, энэ төрлийн судалгааг Дэмбэрэл нар (2006), Хаянхярваа.Б, Цэдэндорж.Л (2011), Пүрэвсүрэн.Г (2011) нарын судлаачид хийсэн бөгөөд эдгээр судалгаагаар 2005- 2006 онд хөрөнгө оруулалтын үр ашиг өндөр байсан бол 2007 оноос хойш хөрөнгө оруулалтын үр ашиг буурах хандлагатай, иймд “хөрөнгө оруулалтын үр ашгийг дээшлүүлж эдийн засгийн өсөлт хөгжпийг тэтгэх талаар онцгой анхаарах шаардлагатай байна" [9]

\section{Судалгаа}

Манай улсын төсвийн хөрөнгө оруулалтын бодлогын хууль эрхзүйн үндсийг Монгол улсын Мянганы хөгжлийн зорилтод суурилсан Үндэсний хөгжлийн цогц бодлого, Бүсчилсэн хөгжлийн үзэл баримтлал, Төсвийн тогтвортой байдлын тухай хууль, Төсвийн тухай хууль, Татварын багц хууль, Засгийн газрын үйл ажиллагааны хөтөлбөр, Нийгэм-эдийн засгийг хөгжүүлэх үндсэн чиглэл, Дунд хугацааны төсвийн хүрээний мэдэгдэл зэрэг эрхзүйн баримт бичгүүд бүрдүүлж байна. Эдгээрээс Үндэсний хөгжлийн цогц бодлого нь төсвийн хөрөнгө оруулалтын бодлогын гол удирдамж болох бөгөөд энэхүҮ баримт бичигт “Төсвийн хөрөнгө оруулалтыг Мянганы хөгжпийн зорилтуудтай оновчтой уялдуулан нэмэгдүүлж, урт, дунд хугацааны хөгжпийн хөтөлбөр, төслүүдэд суурилан хэрэгжүүлнэ хэмээн заагаад 1) Төсвийн бодлого нь төсвийн бодлогын гол цөм асуудлын нэг болдог бөгөөд төсвийн хөрөнгө оруулалтын бодлого, түүний үр өгөөжийг судалж, үнэлэлт дүгнэлт өгсний үндсэн дээр төсвийн хөрөнгө оруулалтын үр ашгийг дээшлүүлэх шаардлага зүй ёсоор урган гарч байна.

гэсэн дүгнэлтийг гаргаж байжээ. Миний хийсэн судалгаа ч мөн ийм үр дүнд хүрснийг судалгааны хэсгээс харж болно. Түүнчлэн гадаадын олон эрдэмтэн, судлаачид төсвийн хөрөнгө оруулалтын эдийн засгийн өсөлтөд үзүүлэх нөлөөллийг судалж, өөрсдийн дүгнэлтийг хийсэн байдаг. Жишээлбэл: Афонса нар (Antonio Afonso \& Miguel St. Aubyn, 2010) Европын Холбооны гишүүн 14 орон болон Япон, Канад, АНУ-ын тоон мэдээлэл дээр үндэслэн дээрх нөлөөллийг шинжпээд төсвийн болон хувийн хөрөнгө оруулалт нь эдийн засгийн өсөлтийг дэмжих хэрэгсэл болж байна [11] гэж дүгнэжээ.

хөрөнгө оруулалтыг зорилтот хөтөлбөрүүд, эдийн засаг, нийгмийн салбарын хөгжпийн мастер төлөвлөгөө, төслүүдэд тулгуурлан хуваарилах; 2) Дэд бүтцийн хөрөнгө оруулалтыг нэмэгдүүлэх; 3) Боловсрол, эрүүл мэндийн салбарт, ялангуяа бүс нутаг, хөдөөд улсын төсвийн хөрөнгө оруулалтыг МянгаНы хөгжпийн зорилтуудтай уялдуулан тогтмол нэмэгдүүлэх; 4) Мэдээлэл, холбооны орчин үеийн техник, технологи нэвтрүүлэх, мэргэжлийн боловсрол олгох тогтолцоог сайжруулахын тулд төсвийн хөрөнгө оруулалтаар дэмжпэг үзүүлэх" [8] зэрэг стратегийн зорилтуудыг дэвшүүлсэн байна. Иймээс манай улсын төсвийн хөрөнгө оруулалтын бодлогын зорилго нь эдгээр зорилтуудыг хэрэгжүүлэхэд чиглэгдэж байна.

"Улсын хөрөнгө оруулалтын хөтөлбөр боловсруулах заавар”-т “ улсын 
хөрөнгө оруулалтын хөтөлбөр нь ЗГ-аас улсын салбарт төлөвлөгөөтэйгээр хөрөнгө оруулж, хувийн хөрөнгө оруулалтыг татах дэд бүтцийн таатай орчинг бүрдүүлэх гол хэрэгсэл болохоос гадна хандивлагч орон, олон улсын банк, санхүүгийн байгууллагуудтай үйл ажиллагаагаa зохицуулах цэгцтэй тогтолцоо болж, тэдгээрийн зээл тусламжийг зохистой удирдах чухал хэрэгсэл болно" [4] гэж заасан нь төсвийн хөрөнгө оруулалтын бодлого зөвхөн эдийн засгийн өсөлтийг дэмжих хэрэгсэл болоод зогсохгүй гадаад өрийн удирдлагад ч чухал үүрэг гүйцэтгэдэг болохыг илэрхийлж байгаа юм.

Төсвийн хөрөнгө оруулалтын бодлогыг хэрэгжүүлэх, үр дүнг дээшлүүлэхэд төсвийн хөрөнгө оруулалтын санхүүжилтын хэмжээ чухал ач холбогдолтой юм. Иймээс төсвийн хөрөнгө оруулалтын зардлын өсөлт, түүний ДНБ, нийт төсвийн зарлага болон төсвийн хөрөнгийн зардалд эзлэх хувийн жингийн өөрчлөлтийг 1990 оноос өнөөг хүртэлх хугацааг хамруулан шинжиллээ.

Зураг 1. Төсвийн нийт хөрөнгө оруулалтын өсөлт (хувиар)

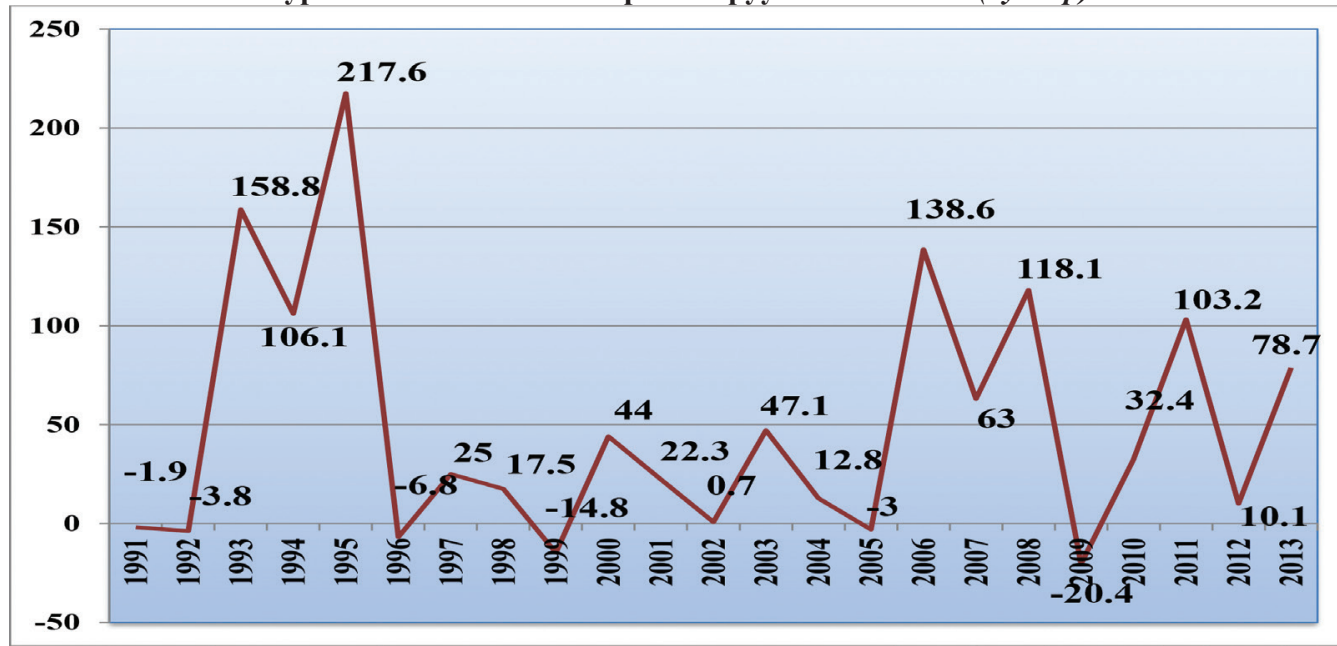

Эх сурвалюс: “Монгол улс зах зээлд” статистикийн эмхтгэл. 2004 Статистикийн эмхтаэл, 2005, 2009, 2011, 2012 он.

Монгол улсын 2013 оны нэгдсэн төсвийн үр дүнгийн үзүҮлэлт. *Урьдчилсан гүйщэтгэл, **Төлөвлөгөө

Зургаас үзэхэд төсвийн хөрөнгө оруулалтын хэмжээ ерөнхийдөө эдийн засгийн мөчлөгтэй холбоотойгоор өөрчлөгдөж байжээ. Тухайлбал: Төсвийн хөрөнгө оруулалтын хэмжээ шилжилтийн үеийн хямралын нөлөөгөөр 1991, 1992 онуудад 3.8 хуртэл хувиар буурчээ. Мөн 1995-1999 онд Азийн орнуудад тохиолдсон эдийн засгийн хямралын нөлөөгөөр 1996 онд 6.8 хувиар, 1999 онд 14.8 хувиар буурсны зэрэгцээ 1997, 1998 онуудад түүний өсөлт удааширсан байна. Түүнчлэн дэлхийн санхүҮ, эдийн засгийн хямралын нөлөөгөөр 2005 онд 3 хувиар багасжээ. Ялангуяа 2009 онд дээрх хугацааны дотор хамгийн өндөр буюу 20.4 хувиар буурсан байна.

Харин 2006 онд уг үзүүлэлт огцом их хэмжээгээр өссөн нь манай улсын экспортын гол нэрийн бүтээгдххүний үнийн өсөлтийн нөлөөгөөр төсвийн орлого эрс нэмэгдсэнтэй холбоотой гэж үзэж байна. Иймээс мөчлөг сөрсөн төсвийн бодлого хэрэгжүүлэх шаардлагатай гэдгийг төсвийн хөрөнгө оруулалтын зардлын өсөлтийн судалгаа давхар харуулж байна. Гэтэл 
МУЗГ- аас төсвийн мөчлөг дагасан бодлого хэрэгжүүлж иржээ. Жишээлбэл: 2009 онд дэлхийн санхүҮ, эдийн засгийн хямралын сөрөг нөлөөгөөр төсвийн орлогын эх үүсвэр хязгаарлагдсанаас нэн чухал бус хөрөнгө оруулалтуудыг хойшлуулах, зогсоох замаар эх үүсвэрийг чөлөөлөх бодлого баримтлан ажилласан байна.

Хэдийгээр дээрх дутагдлууд байгаа боловч сүүлийн жилүүдэд төсвийн хөрөнгө оруулалтын бодлогод нааштай хандлагууд ажиглагдаж байна. Үүнд: 2012 оны төсвийн хөрөнгө оруулалтын бодлогод нийслэлийн төсвөөс улсын төсөвт төвлөрүүлдэг хөрөнгийг “тэглэх" зарчим баримталсан нь орон нутгийн бие даасан байдлыг дээшлүүлэхэд чиглэсэн чухал алхам болжээ. Мөн 2013 оны батлагдсан төсвөөр хөрөнгө оруулалтын зардлын өсөлт нь төсвийн нийт болон урсгал зардлын өсөлтөөс их байна. ИйнхүУ улсын төсвөөс санхүүжүүлэх хөрөнгө оруулалтын хэмжээ эрс нэмэгдэж байгаа нь иргэдийн хөдөлмөр эрхлэлтийг нэмэгдүүлэх замаар бодит орлогыг нь өсгөх, дотоодын аж ахуйн нэгжүүдийн үйл ажиллагааг дэмжих, иргэдийн ая тухтай амьдрах, суралцах орчныг сайжруулах, төрөөс үзүүлэх үйлчилгээний чанар хүртээмжийг дээшлүүлэхэд чухал ач холбогдолтой.

ИйнХүҮ төсвийн хөрөнгө оруулалтын зардал сүүлийн жилүүдэд нэмэгдэж байгаагийн зэрэгцээ ДНБ болон төсвийн нийт зарлагад эзлэх хувийн жин нь ч мөн өсөж байгааг доорхи зургаар харууллаа.

Зураг 2. Төсвийн хөрөнгө оруулалтын зардлын эзлэх хувийн жсин

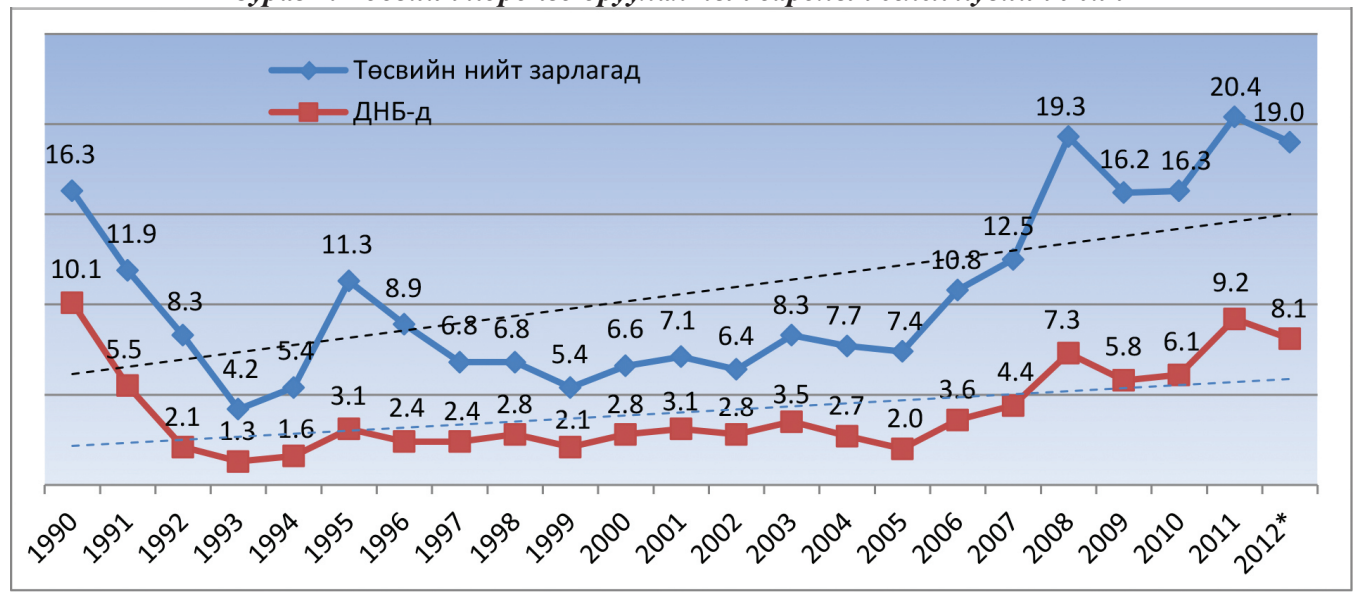

Эх сурвалюс: “Монгол улс зах зээлд” статистикийн эмхтгэл, 2004. Статистикийн эмхтаэл. 2005, 2007, 2009, 2010, 2011, 2012 он.

*Урьдчилсан гүйцฺэтаэл.

Төсвийн хөрөнгө оруулалтын зардлын нийт зарлага болон ДНБ-д эзлэх хувийн жин 2005- 2008 оны хооронд жил дараалан өссөн байгаа нь нэг талаас эдийн засгийн гадаад орчны тааламжтай нөлөвлөл, нөгөө талаас 2007 онд “Монгол улсыг хөгжүүлэх сан” байгуулагдаж, түүнээс улсын эдийн засгийн чадавхийг дээшлүүлэх, жижиг, дунд бизнес /аж ахуйн үйл ажиллагаa/-ийг дэмжихэд чиглэсэн хөрөнге оруулалтыг санхүүжүүлэх болсноор төсвөөс санхүүжүүлэх хөрөнгө оруулалтын зардлыг нэмэгдүүлэх боломж олгосонтой холбоотой юм.

Хэдийгээр төсвийн хөрөнгө оруулалтын зардлын эзлэх хувийн жин сүүлийн жилүүдэд өссөн нааштай Үзүүлэлт харагдаж байгаа хэдий ч тоон 
Үзүүлэлтийн зэрэгцээ хөрөнгө оруулалтын чанар, үр ашгийн асуудлыг анхаарах нь зүйтэй. Учир нь хөрөнгө оруулалтын үр ашгийг дээшлүүлснээр хөрөнгө оруулалт нь жинхэнэ утгаараа эдийн засгийн хөгжпийн гол хөдөлгөгч хүч болно. Иймээс ч Сангийн яамнаас 2011 онд зохион байгуулсан "Хөрөнгө оруулалтын үр өгөөжийг дээшлүүлэх асуудал” сэдэвт онол-практикийн бага хурлаас гаргасан зөвлөмжид Монгол улсын эдийн засгийн өсөлтийг хангах, Үндэсний хөгжпийн цогц бодлого, урт болон дунд хугацаанд дэвшүүлсэн хөгжпийн зорилтуудыг ханган биелүүлэхэд хөрөнгө оруулалтын үр өгөөжийг дээшлүүлэх асуудал чухал ач холбогдолтойг онцлон тэмдэглэсэн байдаг.

Үүнтэй холбоотойгоор төсвийн хөрөнгө оруулалтын үр ашгийг тооцох асуудал зүй ёсоор тавигдаж байгаa юм. Хөрөнгө оруулалтын үр ашгийг үнэлэхэд чиглэгдсэн хөрөнгө оруулалтын үр ашгийн коэффициент, зардлаа нөхөн төлөх хугацаа, өнөөгийн цэвэр үнэ цэнэ, хөрөнгө оруулалтын өгөөжийн хувь зэрэг олон арга, загваруудыг практикт ашиглаж байгаагаас Нэмэгдүүлсэн хөрөнгө - гарцын харьцааны арга нь төсвийн хөрөнгө оруулалтын үр ашгийг тооцоход илүү тохиромжтой юм. Учир нь төсвийн хөрөнгө оруулалтын эцсийн зорилго нь эдийн засгийн буюу ДНБий өсөлтийг хангахад чиглэгддэг. Тэгвэл дээрх аргыг ашигласнаар ДНБ-ий хэмжээг нэгжээр (төгрөгөөр) нэмэгдүүлэхийн тулд хичнээн хэмжээний хөрөнгө оруулалт шаардлагатайг тооцох боломжтой. Үүнийг доорхи томъёогоор [12] илэрхийлэх бөгөөд хөрөнгө оруулалтын үр ашиг өндөр байвал ICOR коэффициент бага байна. Олон улсын хэмжээнд энэхүү коэффициентийн дундаж 3 байдаг.

$$
\text { ICOR }=\frac{\Delta K}{\Delta Y}=\frac{\Delta K / Y}{\Delta Y / Y}=\frac{I / Y}{\Delta Y / Y}=\frac{I}{\Delta Y}
$$

Үүнд: ICOR - Нэмэгдүүлсэн хөрөнгө - гарцын харьцаа

$\Delta \mathbf{K}$ - Нэмэгдүүлсэн хөрөнгө буюу хөрөнгийн өөрчлөлт $\Delta \mathbf{y}$-ДНБ-ий өсөлтййн хэмжээ $\mathbf{y}$ - Гарц буюу ДНБ-ий хзмжээ

I - Хөрөнгө оруулалтын хэмжээ

Үүнээс гадна төсвиийн хөрөнгө оруулалтын үp ашгийг ICOR-ын урвуу хэмжигдэхүүнээр (1/ICOR) тодорхойлж болно. Энэ харьцаа нь нэгж хөрөнгө оруулалтад ногдох ахиуц бүтээгдэхүүн буюу нэмүу өртөг бүтээлтийн хэмжээ бөгөөд уг үзүүлэлт их байх тусам хөрөнгө оруулалтын үрашиг их байгааг, урвуу байвал үр ашиг бага байгааг тус тус илэрхийлдэг [1]. ЭнэхүY онол, аргазүй дээр үндэслэн Монгол улсын нийт болон төсвийн хөрөнгө оруулалтын үр ашгийг МУҮСХ-ноос гаргасан 2002-2012 оны албан ёсны тоон мэдээллүүдийг ашиглан тооцлоо. Үүнд ДНБ болон хөрөнгө оруулалтын үзүүлэлтүүдийг 2005 оны зэрэгцүүлэх үнээр авсан. Ингэхдээ хөрөнгө оруулалтын оны үнийг тухайн оны дефлятороор үржүүлж, 2005 оны зэрэгцүүлэх үнэд шилжүүллээ. Монгол Улсын нийт хөрөнгө оруулалтын хэмжээ ба ДНБ-ий өсөлтөд үндэслэн тооцсон ICOR -ыг зургаар харууллаа.

Тооцооллоос үзэхэд 2004 онд нийт хөрөнгө оруулалтаас тооцсон ICOR 2.59 байсан нь тооцоонд хамрагдсан хугацааны хамгийн бага үзүүлэлт буюу нийт хөрөнгө оруулалтын үр ашиг хамгийн их байсныг харуулж байна. Хөрөнгө оруулалтын өгөөжийн коэффициент мөн онд хамгийн их буюу 0.39 хүрсэн нь нэг төгрөгийн хөрөнгө оруулалтаар 0.39 төгрөгийн нэмүҮ бүтээгдэхүүн үйлдвэрлэж чадсаныг илтгэж байгаа юм. 2005 оноос эхлэн хөрөнгө оруулалтын үр ашиг ерөнхийдөө (руурсаар ирсэн бөгөөд 2009 онд нийт хөрөнгө орууулалтын ICOR 15.18 хүрч, өгөөж нь 0.07 болсон нь дээрх хугацааны хамгийн бага үзүүлэлт болж байна. Хэдийгээр 2010 оноос нийт хөрөнгө оруулалтын үр ашиг 2009 онтой харьцуулахад өссөн боловч дэлхийн бусад орнуудын дундаж буюу хэвийн хэмжээнээс бага байгаа нь хөрөнгө оруулалтын үр ашгийг нэмэгдүүлэх шаардлагатайг харуулж байна.

Улсын төсвийн хөрөнгө оруулалтын 
үр ашгийг тооцож үзэхэд дэзрх хандлага харж болно.

мөн л ажиглагдаж байгааг доорхи зургаас

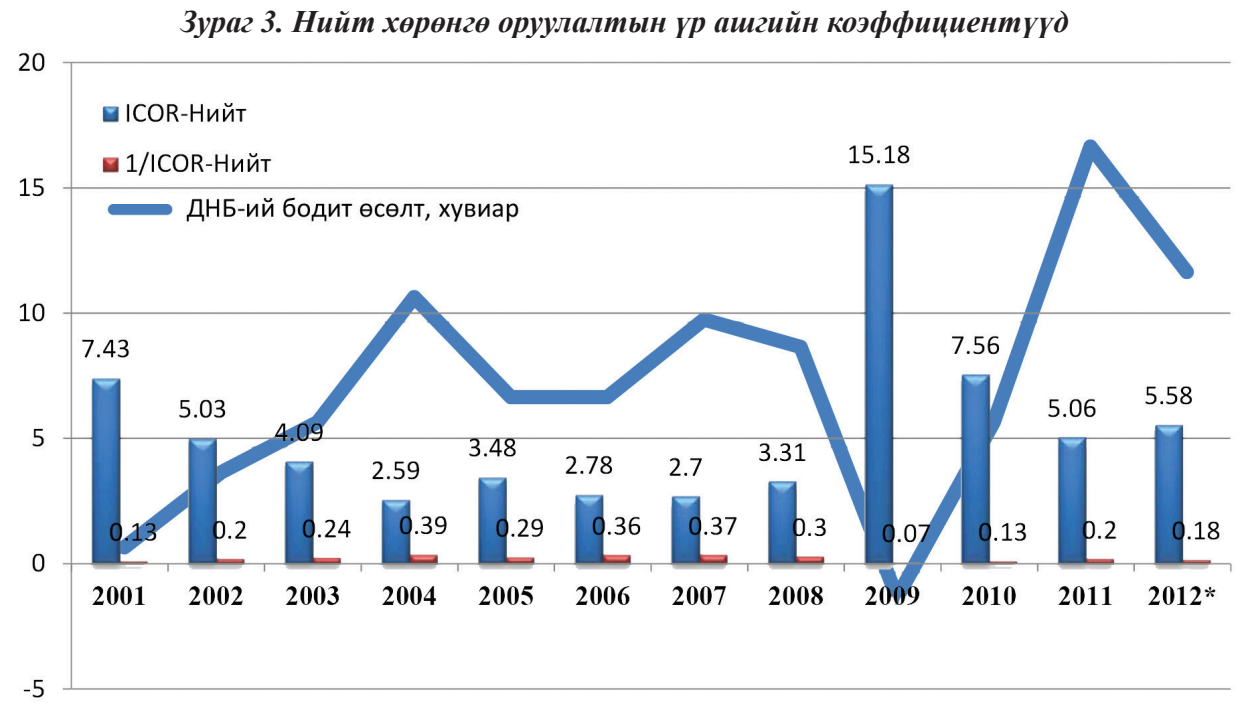

Эх сурвалю: Статистикийн эмхтгэл. 2002, 2004, 2006, 2009, 2012 он. http://www.1212.mn-ээс авсан тоон ҮзҮүлэлтүҮд дээр үндэслэн тооцов.

*Урьдчилсан гүйцэтгэл.

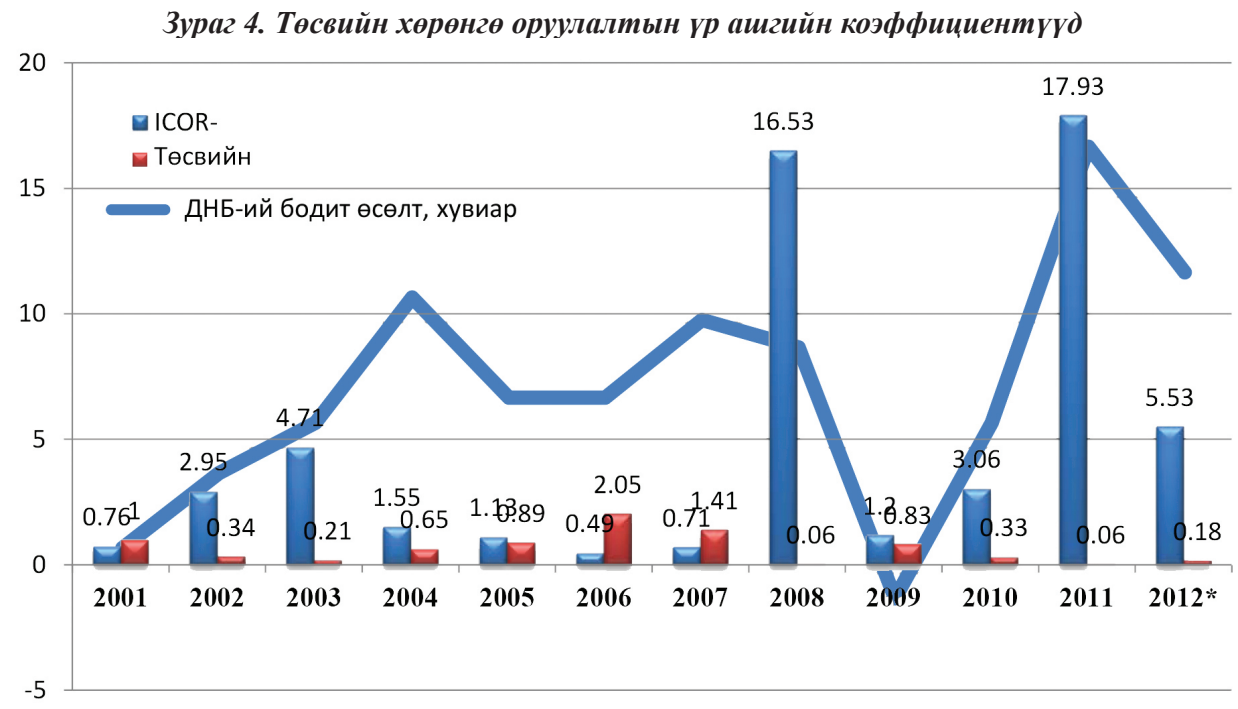

Эх сурвалюк: Статистикийн эмхтгэл. 2002, 2004, 2006, 2009, 2012 он. http://www.1212.mn-ээс авсан тоон ҮзҮүлэлтүҮд дээр үндэслэн тооцов.

*Урьдчилсан гүйцэтгэл.

2004-2007 онд улсын төсвийн үйлдвэрлэхийн тулд дунджаар 0.97 төгрөг хөрөнгө оруулалтын үр ашиг их байсан зарцуулж байжээ. Харин 2008, 2011 бөгөөд нэг төгрөгийн нэмүү бүтээгдэХүүн онуудад нэг төгрөгийн төсвийн хөрөнгө -49 - 
оруулалтаар дөнгөж 0.06 төгрөгийн нэмүҮ бүтээгдэхүүн үйлдвэрлэсэн нь төсвийн хөрөнгө оруулалтын үр ашиг бага байсныг харуулж байна. Гэтэл эдгээр онуудад манай улсын эдийн засгийн өсөлт өндөр байсан төдийгүй төсвийн хөрөнгө оруулалтын хэмжээ өмнөх оноос 2008 онд 42.5 хувь буюу 532.3 тэрбум төгрөгөөр, 2011 онд 118 хувь буюу 4542.1 тэрбум төгрөгөөр тус тус нэмэгджээ. Үүнээс дүгнэлт хийхэд манай улсын эдийн засгийн өсөлт нь хөрөнгө оруулалтын үр ашгаар биш, харин хөрөнгө оруулалтын хэмжээний өсөлтөөр хангагдаж байна. Түүнчлэн 2012 оны урьдчилсан гүйцэтгэлээр төсвийн хөрөнгө оруулалтаас тооцсон ICOR 5.53 байгаа нь нэг төгрөгийн нэмүү бүтээгдэхүүн үйлдвэрлэхийн тулд улсын төсвөөс 5.53 төгрөгийн хөрөнгө оруулалтын зардал гаргасан гэсэн үг. Энэ нь төсвийн хөрөнгө оруулалтын үр ашиг хангалтгүйг илтгэж байгаa юм.

Энэ бүхнээс хөрөнгө оруулалтын үр ашгийг дээшлүүлэх шаардлага зүй ёсоор урган гарч байна. Хөрөнгө оруулалтын үр ашгийг дээшлүүлэхийн тулд зөвхөн санхүүгийн эх үүсвэрээр хангах төдийгүй хөрөнгө оруулалтын хэрэгцээг зөв тодорхойлох, ажиллах хүчний чадварыг сайжруулах, техник технологийн дэвшлийг нэвтрүүлэх шаардлагатай байдаг. Иймээс төсвийн хөрөнгө оруулалтын үр ашгийг гүнзгийрүүлэн судлах зорилгоор түүний бүтцийн судалгааг хийлээ.

Зураг 5. Төсвийн хөрөнгө оруулалтын бүтэц (зардлын төрлөөр, хувиар)

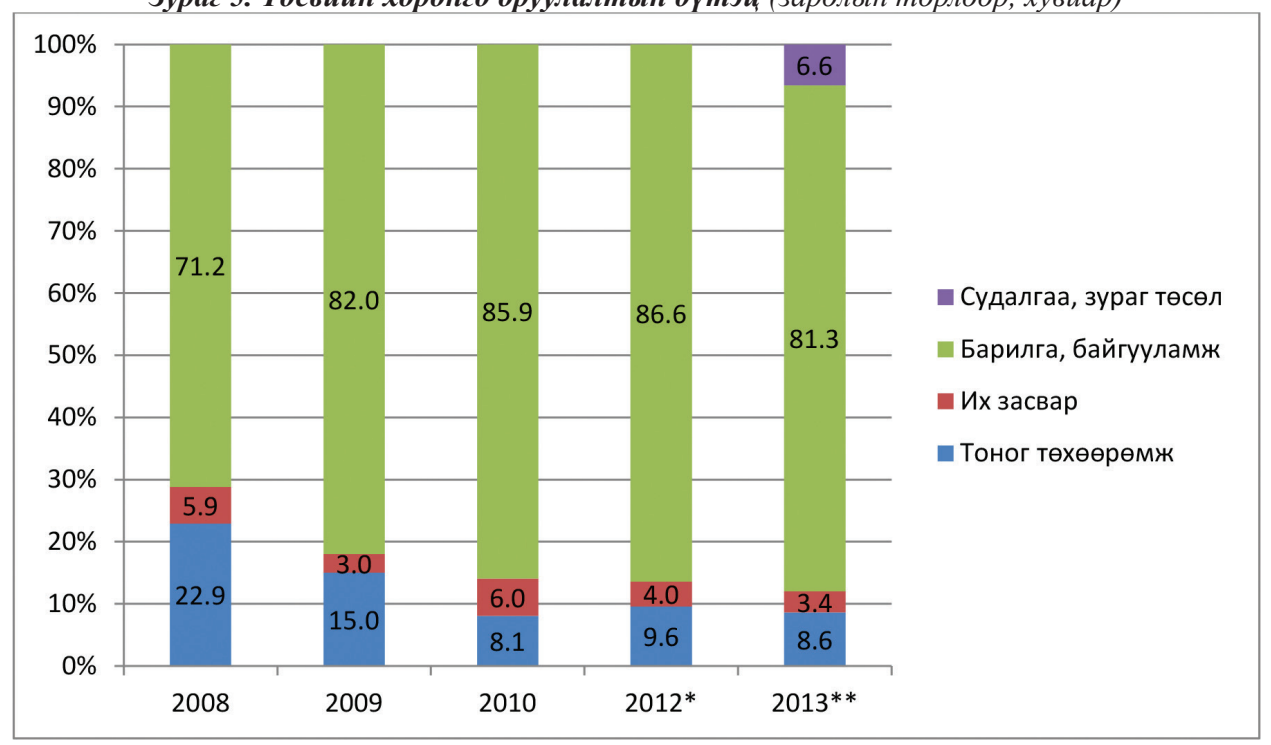

Эх сурвалюс: Монгол улсын 2010 оны нэгдсэн төсвийн гүйщฺэтгэл, ЗГ-ын санхуүгийн нэгтгэсэн тайлан.

СЯ. 2012 оны 12 сарын төсвийн гүйцэтгэл. Монгол улсын 2013 оны нэгдсэн төсвийн үр дүнгийн ҮзҮҮлэлт.

*Урьдчилсан гүйцээтгэл. *Төлөвлөгөө.

Төсвийн хөрөнгө оруулалтын зардлын бүтцийг авч үзэхэд барилга байгууламжийн зардал нийт зардлын 80 гаруй. хувийг эзэлж байгаа нь төрөөс дэд бүтцийн барилга байгууламжийг барих, шинэчлэх, өргөтгөх, нийгмийн салбарт түлхүү хөрөнгө оруулах бодлого баримталж байгаатай холбоотой. Энэ нь иргэдийн сурч боловсрох, амьдрах таатай нөхцөлийг бүрдүүлэх ач холбогдолтой юм. Гэсэн ч тоног төхөөрөмжийн зардлын эзлэх хувийн жин жил бүр буурсаар байна. Тухайлбал, 
тоног төхөөрөмжийн зардлын төсвийн хөрөнгө оруулалтад эзлэх хувийн жин 2008 оноос эрс буурч, 2013 оны төлөвлөгөөгөөр дөнгөж 8.6 хувийн эзлэх болжээ. Үүний улмаас дэвшилтэт техник, технологи нэвтрүүлэх бодлого хоцорч, хөрөнгө

\section{Дүгнэлт}

МУ-ын төсвийн хөрөнгө оруулалтын байдалд хйисэн судалгаа, шинжилгээний үр дүнгээс үзэхэд төсвийн хөрөнгө оруулалтын хэмжээ ерөнхийдөө эдийн засгийн мөчлөгтэй холбоотойгоор өөрчлөгдөж иржээ. Энэ нь манай улсын Засгийн газраас төсвийн мөчлөг дагасан бодлого хэрэгжүүлж ирсний тод илэрхийлэл юм. Төсвийн хөрөнгө оруулалтын зардлын хэмжээ, түүний ДНБ болон төсвийн нийт зарлагад эзлэх хувийн жин өссөөр байна. Гэвч төсвийн хөрөнгө оруулалтын үр ашиг хангалтгүй байгаагаас манай улсын эдийн засгийн өсөлт нь хөрөнгө оруулалтын үр ашгаар биш, харин хөрөнгө оруулалтын хэмжээний өсөлтөөр хангагдаж байна. Энэ нь ажилгүйдэл, ядуурлыг бууруулах, иргэдийн аж байдлыг сайжруулахад хөрөнгө оруулалт мэдэгдэхүйц нөлөө үзүүлж чадахгүй байгаагаас тодорхой харагдаж байгаа юм. Иймээс хөрөнгө оруулалтын үр ашгийг нэмэгдүүлэхийн тулд доорхи арга хэмжээнүүдийг авч хэрэгжүүлэх нь зүйтэй гэж үзэж байна. Үүнд:

1. Хөрөнгө оруулалтын бүтцийг сайжруулж, техник, технологи, инновацийг нэвтрүүлэхэд чиглэсэн зардлын эзлэх хувийн жинг нэмэгдүүлэх, төсвийн нийт зарлагад хөрөнгө оруулалтын эзлэх хувийн жингийн доод хязгаарыг зааж өгөх;

2. Төсвийн хөрөнгө оруулалтын үр оруулалтын үр ашигт сөрөг нөлөө үзүүлж болзошгүй юм. Мөн их засварын зардлын эзлэх хувийн жин 2013 оны төлөвлөгөөгөөр 2008 онтой харьцуулахад 1.7 дахин буурсан байна.

ашгийгтооцох нэгдсэн арга, аргачлалыг баталж, мөрдүүлэх;

3. Улс орны эдийн засгийн хөгжилд тэргүүлэх ач холбогдол бүхий эдийн засгийн салбар, тэр дундаа ХАA, боловсруулах үйлдвэрлэлийн салбарыг дэмжихэд хөрөнгө оруулалтын бодлогыг чиглүүлэх, эдгээр салбарыг хөгжүүлэхэд шаардлагатай дэд бүтцийн асуудлыг шийдвэрлэхэд шаардлагатай хөрөнгө оруулалтыг цаашид нэмэгдүүлэх;

4. Төсвийн тогтворжуулалтын сангийн ДНБ-ий 10 хувиас давсан хэсгээс байгуулсан “Хөрөнгө оруулалтын сан”-гийн хөрөнгөөр эдийн засгийн салбарууд дахь хөрөнгө оруулалтын үйл ажиллагааг санхүүжүүлдэг ОХУ-ын туршлагыг нэвтрүүлэх.

5. Холбооны хөрөнге оруулалтыг үр дүнд үндэслэн хуваариладаг ОХУын туршлагыг хэрэгжүүлэх, Үүний тулд хөрөнгө оруулалтын бодлогыг хөрөнгө оруулалтын төслүүдийн ICOR коэффициентыг тооцсоны үндсэн дээр боловсруулдаг болох;

6. Төсвийн төлөвлөлтийг дунд хугацаанд баримтлах улсын хөрөнгө оруулалтын хөтөлбөр, хөгжпийн бодлого, стратеги төлөвлөлттэй нягт уялдуулах, хөрөнгө оруулалтын эрх зүйн орчинг боловсронгуй болгох. 


\section{Аиигласан бүтээлийн жсагсаалт}

1. Дэмбэрэл. Л нар, 2006. Монгол Улсын 2005 оны төсвийн төлөвлөлт, гүйиэтгэлд хийсэн мэргэжсийн шинжслгээ: Тайлан, дүгнэлт, санал, зөвлөмж, аргачлал, загвар, программ хангамж. Сангийн яам, Эдийн засгийн чадавхийг бэхжүүлэх техник туслалцааны зээл (ЕСТАС)-ийн төсөл, Дэлхийн банк, УБ.

2. Монгол улсын 2010 оны нэгдсэн төсвийн гүйцэтгэл, ЗГ-ын санхүүгийн нэгтгэсэн тайлан.

3. Монгол улсын 2013 оны нэгдсэн төсвийн үр дүйгийн Үзүүлэлт.

4. МУЗГ-ыл 2010 оны 123 дугаар тоггоольн хавсралт. Улсын хөрөнгө оруулалтын хөтөлбөр боловсруулах нийтлэг журам.

5. МУУСГ, 2004. “Монгол улс зах зээлд” статистикийн эмхтгэл.

6. МУУСХ. Статистикийн эмхтгэл, 2005, 2009, 2011, 2012 он.

7. СЯ. 2012 оны 12 сарын төсвийн гүйиэтгэл.

8. УИХ, 2008. Монгол Улсын мянганы хөгжпий зорилтод суурилсан Үндэсний хөгжпийн ичоги бодлого. УБ.

9. Хаянхярваа Д., Цэдэндамба Л., 2011. “Монгол Улсын хөрөнгө оруулалтын өнөөгийн байдал, тулгамдсан асуудлууд, шийдвэрлэх арга замууд”: илтгэл. УБ.

10. http://www.1212.mn/

11. Antonio Afonso \& Miguel St. Aubyn, 2010. "Public and private investment rates of return: evidence for industrialized countries, ” Applied Economics Letters, Taylor and Francis Journals, vol. 17(9).

12. http://en.wikipedia.org/wiki/lncremental_capital-output_ratio 